\title{
The Effect of Silicon Nanoparticles on the Seed Germination and Seedling Growth of Moso Bamboo (Phyllostachys edulis) under Cadmium Stress
}

\author{
Abolghassem Emamverdian ${ }^{1,2}$, Yulong Ding ${ }^{1,2 *}$, Farzad Mokhberdoran ${ }^{1,3}$, \\ Zishan Ahmad ${ }^{1,2}$, Yinfeng Xie ${ }^{1,4}$ \\ ${ }^{1}$ Co-Innovation Center for Sustainable Forestry in Southern China, Nanjing Forestry University, Nanjing, 210037, China \\ ${ }^{2}$ Bamboo Research Institute, Nanjing Forestry University, Nanjing, 210037, China \\ ${ }^{3}$ Department of Agronomy and Plant Breeding, Faculty of Agriculture, Islamic Azad University, \\ Mashhad Branch, Mashhad 9187147578, Iran \\ ${ }^{4}$ College of Biology and the Environment, Nanjing Forestry University, Nanjing, 210037, China
}

Received: 2 October 2020

Accepted: 19 November 2020

\begin{abstract}
In the current study, the impact of silicon nanoparticles on germination characteristics and key growth parameters was investigated in Moso bamboo seedlings under cadmium (Cd) stress. The seeds were germinated at a concentration of $100 \mu \mathrm{M} \mathrm{Cd}$ alone and in combination with two levels of $\mathrm{SiO}_{2}$ NPs $(100$ and $200 \mu \mathrm{M})$, and the results were compared with those from a control treatment. The results indicated that $\mathrm{SiO}_{2}$ NPs significantly improved germination characteristics (GP, GR, and GI) under Cd toxicity but also led to increased mean germination time (MGT). On the other hand, the results indicated that the seedling growth indexes, seedling biomass and vigor indexes of Moso bamboo improved under a combination of $100 \mu \mathrm{M} \mathrm{Cd}$ and silicon nanoparticles. We concluded that $\mathrm{SiO}_{2} \mathrm{NPs}$ could ameliorate cadmium toxicity during seed germination and that the enhanced germination parameters improved seedling growth in Moso bamboo under Cd toxicity. We also found that $\mathrm{SiO}_{2} \mathrm{NPs}$ at $200 \mu \mathrm{M}$ rather than $100 \mu \mathrm{M}$ had a greater beneficial impact on the seed germination and the seedling growth under the $\mathrm{Cd}$ stress of $100 \mu \mathrm{M}$. Thus, the use of $\mathrm{SiO}_{2}$ NPs may help in controlling Cd toxicity at the stages of seed germination and seedling growth in Moso bamboo (Phyllostachys edulis).
\end{abstract}

Keywords: silicon nanoparticles, germination, Moso bamboo, cadmium

*e-mail: ylding@vip.163.com 


\section{Introduction}

In recent decades, the contamination of soil and the environment caused by anthropogenic activities has led to rising levels of heavy metals in the soil and environment in the southern and eastern China, and heavy metal pollution is considered a major factor threatening human health [1]. Studies have reported that in China, more than $2 \times 107 \mathrm{hm}^{2}$ (approximately $20 \%$ ) of the total agricultural soils are polluted by heavy metal contamination caused by sewage [2]. Among heavy metals, cadmium (Cd) is one of the most widespread metals in this area and is one of the elements with the highest pollution levels in Chinese farmland soil [3]. Cadmium has polluted more than $1.133 \times 10^{7} \mathrm{hm}^{2}$ of China's agricultural soil [2]. Extremely high levels of $\mathrm{Cd}$ can lead to a decrease in plant growth $[4,5]$ and development as well as a reduction in yield [6].

The seed germination stage is regarded as the most important part of the plant life cycle $[7,8]$. The reduction of germination and seedling growth in many plant species under heavy metal and salt stress is observed [9]. Silicon, as the second most abundant element in surface soils, can help plant species under stress conditions [10]. Many researchers have reported that silicon can reduce $\mathrm{Cd}$ stress in plants by different mechanisms. As for wheat and rice plants, silicon reduces or entirely inhibits the translocation of $\mathrm{Cd}$ to shoot and reproductive organs [11, 12] and in cowpea, silicon is shown to effect the accumulation and deposition of $\mathrm{Cd}$ in the roots or (root zone) [13]. The reduced metal accumulation in plant species facilitated by silicon can positively contribute to plant growth and development $[14,15]$.

In recent years, researchers have focused on using nanoparticles for agricultural purposes [16]. Nanoparticles are made of three-dimensional spheres with a size between 1 and $100 \mathrm{~nm}[17,18]$. Nanoparticles have high surface area and high solubility, and they can change their physico-chemical properties. Therefore, they are well known as a unique material [19]. The adsorption mechanism by $\mathrm{SiO}_{2}$ NPs when plants are subjected to the excess of heavy metals can lead to the reduction in lethal concentration of metals in plants [20]. There is some evidence that $\mathrm{SiO}_{2}$ NPs impacts seed germination. Siddiqui and Al-whaibi reported that $\mathrm{SiO}_{2} \mathrm{NPs}$ improved seed germination in tomato [21]. Suriyaprabha obtained a similar result when studying the effect of $\mathrm{SiO}_{2} \mathrm{NPs}$ on Zea mays seeds [22]. Moreover, the growth indexes of Changbai larch seedlings [23], maize (Zea mays L.) [24], tomato seed germination [25, 26], and Arabidopsis thaliana [27] were reported to be positively influenced by $\mathrm{SiO}_{2}$ NPs under various stress conditions. However, the impact of $\mathrm{SiO}_{2}$ NPs on bamboo seed germination and growth under $\mathrm{Cd}$ stress is still not completely understood. To our knowledge, this study may be the first to investigate the role of $\mathrm{SiO}_{2} \mathrm{NPs}$ in the reduction of cadmium toxicity in Moso bamboo seed germination and seedling growth.
Moso bamboo (Phyllostachys edulis) is one of the greatest hyperaccumulator species and makes up more than $70 \%$ of the bamboo species in forests in China $[28,29,30,31]$. This fast-growing plant covers more than three million hectares of forest in China [32-34], which are distributed in bamboo forest areas in 12-13 provinces in southern China $[35,36]$. Soil contamination by heavy metals has become a significant crisis in this region [3]. Moso bamboo, which has a large timber and shoot biomass, should be investigated as a potential heavy metal remediation species [32, 37]. Moso bamboo is also known for having a strong ability to accumulate silicon in the environment [38], which may help to reduce heavy metal contamination [39]. This study explored the possible ameliorative impacts of two levels of $\mathrm{SiO}_{2} \mathrm{NPs}$ on Cd toxicity in seed germination and seedling growth indexes of Moso bamboo (Phyllostachys edulis).

\section{Materials and Methods}

This study was conducted in the seed germination room of the Bamboo Research Institute, Nanjing Forestry University. For this purpose, the seeds of Moso bamboo (Phyllostachys edulis) were collected from the seed bank of the Bamboo Research Institute in Jiangsu Province. In the first step, the bamboo seeds were separated from the skin and sterilized with disinfection powder (Duo Jun Ling) twice for $30 \mathrm{~min}$. The seeds were dispersed into the water for the separation of the empty seeds and were soaked in water for 12 hours. In this research, the treatments were in a completely randomized design with four replications for each treatment. The treatments included a control (Wild Type), $100 \mu \mathrm{M} \mathrm{Cd}, 100 \mu \mathrm{M}$ Cd-100 $\mu \mathrm{M} \mathrm{SiO}_{2}$ NPs, and $100 \mu \mathrm{M} \mathrm{Cd}-200 \mu \mathrm{M} \mathrm{SiO}_{2}$ NPs (Fig. 1).

Approximately 100 seeds were used in each treatment. To separate the nanoparticles from each other and create a suspension, homogenization was conducted in solution with an ultrasonic device $(100 \mathrm{~W}$, $40 \mathrm{kHz}$ ). For the preparation of the treatments, the seeds

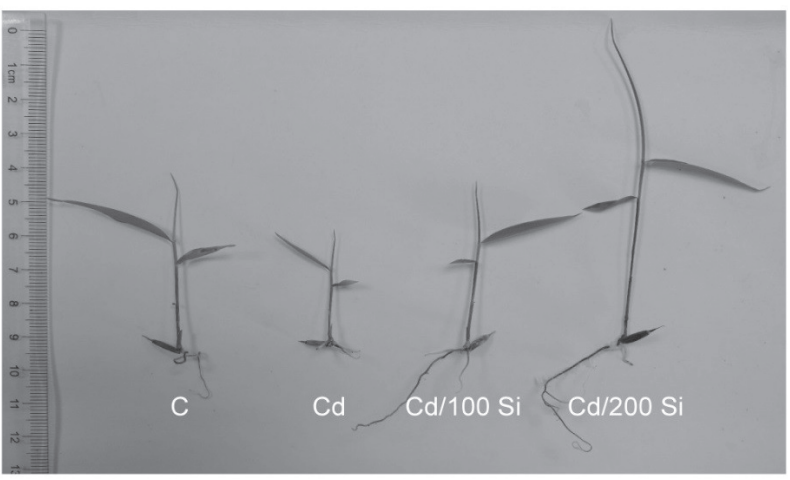

Fig. 1. Moso bamboo as affected by $100 \mu \mathrm{M} \mathrm{Cd}$ alone and in combination with $100 \mu \mathrm{M}$ or $200 \mu \mathrm{M} \mathrm{SiO}_{2}$ NPs. 
were set on duplexed wet paper in a Petri dish that was stuffed with cotton. The experiment was conducted in a germination device with an optimal temperature of $25^{\circ} \mathrm{C}$ and 1000 lux (12 hours light - 12 hours darkness) light intensity, which was maintained at $60 \%$ humidity for 30 days.

To measure the germination characteristics during the seedling period, the number of germinated seeds was counted daily at a specified hour. Afterward, the germination characteristics were determined using the formulas below.

A. (Germination index) (Tekrony and Egli, 1990) [40].

$$
\mathrm{GI}=\left(\mathrm{n} \cdot \mathrm{t}^{-1}\right)
$$

B. (Germination percentage) (Khodarahmpour, 2012) [41].

$$
\mathrm{GP}=(\mathrm{n} / \mathrm{N}) \times 100
$$

C. (Germination rate) ( Khodarahmpour, 2012) [41].

$$
\mathrm{GR}=£\left(\mathrm{n} \cdot \mathrm{t}^{-1}\right)
$$

D. (Mean germination time) (Agrawal and Dadrani, 1995) [42].

$$
\text { MGT }=£(n . t) . £ n^{-1}
$$

$\mathrm{n}=$ the number of seeds that germinated on day $\mathrm{t}$.

$\mathrm{N}=$ total number of seeds.

\section{Seedling Growth Characteristics}

The seedling growth was evaluated based on the shoot and root length. It was measured on the last day of the germination experiment and after separating irrigated seeds from hard and desiccated seeds. Ten germinated seeds were randomly selected from each treatment, and the growing parts of the embryo were separated from the storage parts (cotyledons). The root length, seedling height, and stem length were measured manually with a ruler [42].

\section{Seedling Biomass Determination}

The seedling roots and seedling shoots were carefully cleaned. In the first step, the water on all surfaces was removed by drying the samples in an oven at $110^{\circ} \mathrm{C}$ for $10 \mathrm{~min}$. The samples were then dried for $20 \mathrm{~min}$ at $80^{\circ} \mathrm{C}$ to a constant dry weight.

\section{Vigor Indexes}

The vigor indexes of seed germination were obtained by the following formulas:

Vigor index I = standard germination percentage $(\mathrm{SGP}) \times$ the mean seedling length $(\mathrm{mm})$
Vigor index II = standard germination percentage $(\mathrm{SGP}) \times$ the mean seedling weight $(\mathrm{g})$

The measurement of cadmium and silicon contents in roots, and leaves of Moso bamboo.

The contents of $\mathrm{Cd}$ were measured in the roots, and leaves of Moso bamboo (Phyllostachys edulis) seedling at the end of the experiment. In this process, the samples were first cleaned and then dried and dissolved in $70 \%$ nitric acid for $15 \mathrm{~min}$ at the temperature of $70^{\circ} \mathrm{C}$. Then, to collect the supernatants, the samples were centrifuged at $12000 \mathrm{~g}$ for $5 \mathrm{~min}$. The cadmium and silicon contents in the roots and leaves were measured by atomic absorption spectrometry (AAS), which uses a spectrometer equipped with a furnace of graphite and a Zeeman-effect background correction system (AAnalyst 800, Perkin Elmer). To determine the amount of the elements, the parameters of the instruments were optimized. Then, the metal standards were calculated and recorded in the range of $2.5 \%$ nitric acid (Spectrascan). The calibration verification standard (Perkin Elmer) included all the elements in the inorganic target analyst list (TAL) and was run at optimal intervals in an unattended automatic analysis run.

\section{Scanning Electron Microscope (SEM) Analysis of Leaf and Root Surfaces}

Observations of the germination organs (leaves and roots) were performed using a scanning electron microscope (SEM) (JSM-6380, JEOL, Tokyo, Japan) operating at $15-25 \mathrm{kV}$. Briefly, the selected leaves and roots were fixed in $70 \%$ FAA consisting of a formaldehyde solution and glacial acetic acid and kept at $4^{\circ} \mathrm{C}$ overnight in a vacuum. The next day, the samples were cut horizontally or vertically from the surface to meet the requirements of imaging, and the final wash was administered with $80 \%$ acetone. Then, the samples were transferred to the Test Center Lab at Nanjing Forestry University, where the samples were dried on a platform before microscopic observation.

\section{Statistical Analysis}

This study was carried out using a completely randomized design (CRD) with four replicates. Analysis of variance (ANOVA) was performed using the statistical software package $\mathrm{R}$. The mean differences were determined using Tukey's test at the $\mathrm{p}<0.05$ probability level.

\section{Results}

\section{Seed Germination Characteristics}

In the studied species, the differences in the germination index (GI) among the various 
concentrations of $\mathrm{Cd}$ and $\mathrm{SiO}_{2} \mathrm{NPs}$ and the control treatment were significant at the $1 \%$ level $(\mathrm{p}<0.01)$. According to the results, the $100 \mu \mathrm{M} \mathrm{Cd}+200 \mu \mathrm{M} \mathrm{SiO}_{2}$ NPs treatment had the highest germination index (GI), with a $15 \%$ increase over that of the control treatment. The $100 \mu \mathrm{M} \mathrm{Cd}$ treatment had the lowest germination index, with a $28 \%$ reduction compared with that of the control treatment. The results obtained by our data analysis indicated that there were significant differences in the germination rate (GR) among the different concentrations of $\mathrm{Cd}$ and $\mathrm{SiO}_{2} \mathrm{NPs}$ and the control treatment $(\mathrm{P}<0.01)$. The germination rate $(\mathrm{GR})$ in the $100 \mu \mathrm{M} \mathrm{Cd}+200 \mu \mathrm{M} \mathrm{SiO}_{2}$ NPs, $100 \mu \mathrm{M} \mathrm{Cd}+100 \mu \mathrm{M}$ $\mathrm{SiO}_{2} \mathrm{NPs}$, and $100 \mu \mathrm{M} \mathrm{Cd}+0 \mu \mathrm{M} \mathrm{SiO}{ }_{2}$ NPs treatments showed 1.40-, 1.28- and 1.22-fold increases, respectively, in comparison with that of the control treatment. The germination percentage (GP) showed similar results as the germination rate. There were significant differences in germination percentage between the various concentrations of $\mathrm{Cd}$ and $\mathrm{SiO}_{2} \mathrm{NPs}$ and the control treatment. The results indicated that the germination percentage (GP) increased with the addition of $\mathrm{SiO}_{2}$ NPs. The germination percentage (GP) in the $100 \mu \mathrm{M}$ $\mathrm{Cd}+100 \mu \mathrm{M} \mathrm{SiO}_{2} \mathrm{NPs}_{\text {s }}$ and $100 \mu \mathrm{M} \mathrm{Cd}+200 \mu \mathrm{M} \mathrm{SiO}_{2}$ NPs treatments were $12 \%$ and $24 \%$ higher than that in the control treatment, respectively. The data analysis also revealed a significant reduction in the germination percentage (GP) in the $100 \mu \mathrm{M} \mathrm{Cd}$ treatment without $\mathrm{SiO}_{2} \mathrm{NPs}$; in that treatment, the germination percentage (GP) decreased by $25 \%$ in comparison with that of the control treatment. The mean germination time (MGT) was another critical seed germination index. According to the data analysis, there were significant differences between the different concentrations of $\mathrm{SiO}_{2} \mathrm{NPs}$ and the control treatment $(p<0.01)$, showing that the mean germination time increased with the addition of silicon NPs and $\mathrm{Cd}$. The mean germination times were 3.9, 4.6, 4.6 and 6.5 days in the control, $100 \mu \mathrm{M} \mathrm{Cd}+0 \mu \mathrm{M}$ $\mathrm{SiO}_{2} \mathrm{NPs}, 100 \mu \mathrm{M} \mathrm{Cd}+100 \mu \mathrm{M} \mathrm{SiO}_{2} \mathrm{NPs}$, and $100 \mu \mathrm{M}$ $\mathrm{Cd}+200 \mu \mathrm{M} \mathrm{SiO}_{2}$ NPs treatments, respectively.

\section{Seedling Growth Characteristics}

\section{Shoot Length and Root Length}

The results obtained from the different combinations of $\mathrm{Cd}$ and $\mathrm{SiO}_{2}$ NPs for the root and shoot length indicated that there were significant differences between the various concentrations of $\mathrm{Cd}$ and $\mathrm{SiO}_{2} \mathrm{NPs}$ and the control treatment $(\mathrm{p}<0.01)$. In treatments with a high concentration of silicon in combination with $\mathrm{Cd}$ $(100 \mu \mathrm{M} \mathrm{Cd}+200 \mu \mathrm{M} \mathrm{SiO} 2 \mathrm{NPs})$, the shoot and root lengths were $24 \%$ and $55 \%$ higher, respectively, than those of the control. However, the results showed that exposure to $100 \mu \mathrm{M} \mathrm{Cd}$ reduced the shoot and root length by $21 \%$ and $10 \%$ compared with the control treatment, which revealed the role of $\mathrm{SiO}_{2} \mathrm{NPs}$ in the reduction of $\mathrm{Cd}$ toxicity in the seedling root and shoot growth stages.

\section{Seedling Biomass Characteristics}

Shoot and Root Dry Weight

In this study, the seedling biomass was calculated according to the measurements of root and shoot dry weight. The data analysis of the effects of the different treatments on the root and shoot dry weight indicated that there were significant differences between the different concentrations of $\mathrm{Cd}$ and $\mathrm{SiO}_{2}$ NPs and the control treatment $(\mathrm{p}<0.01)$. A high concentration of $\mathrm{SiO}_{2}$ NPs resulted in the highest root and shoot dry weight, with 1.28 - and 1.51-fold increases, respectively, in comparison with those of the control treatment. This result demonstrates that $\mathrm{SiO}_{2}$ NPs could help to increase biomass in seedlings growing under cadmium toxicity. On the other hand, the results revealed that $100 \mu \mathrm{M}$ $\mathrm{Cd}$ reduced root and shoot dry weight by 1.32 - and 1.45 -fold, respectively, compared with those in the control treatment. Moreover, this result indicated the negative impact of $100 \mu \mathrm{M}$ cadmium on seedling biomass.

\section{Vigor Indexes}

Vigor Index (I) and Vigor Index (II)

The investigation of vigor indexes during seed germination indicated significant differences between the various concentrations of $\mathrm{Cd}$ and $\mathrm{SiO}_{2} \mathrm{NPs}$ and the control treatment $(\mathrm{p}<0.01)$. According to the results, $\mathrm{SiO}_{2}$ NPs significantly increased seed vigor in bamboo seeds under cadmium stress. The data indicated that the concentrations of $\mathrm{Cd}$ and $\mathrm{SiO}_{2} \mathrm{NPs}$ enhanced vigor index (I) and vigor index (II) by $62 \%$ and $137 \%$, respectively, compared with those of the control treatment. On the other hand, cadmium had a damaging impact on seed germination. The data showed a reduction of $41 \%$ and $44 \%$ in vigor index (I) and vigor index (II), respectively, compared with those in the control treatment.

\section{The Measurement of Heavy Metal and Silicon Contents in the Bamboo Seedling Roots, and Leaves}

It is obvious that silicon has the ability to regulate metal accumulation in leaves through mechanisms such as decreasing metal distribution (immobility) within leaves cells and the limitation of metal translocation from root to shoot, which can reduce metal toxicity in plants. Cd accumulation in the roots and leaves of the bamboo seedling displayed significant differences between the accumulated amounts of cadmium and the various levels of cadmium $(\mathrm{p}<0.01)$. Based on the results, the combination of $100 \mu \mathrm{M}$ cadmium, $100 \mu \mathrm{M}$ cadmium- $\left(100 \mu \mathrm{M} \mathrm{SiO}_{2} \mathrm{NPs}\right)$ and, $100 \mu \mathrm{M}$ cadmium$\left(200 \mu \mathrm{M} \mathrm{SiO}_{2} \mathrm{NPs}\right)$ resulted in accumulation of $3.27 \mu \mathrm{g}$, $1.56 \mu \mathrm{g}$, and $0.76 \mu \mathrm{g}$ of $\mathrm{Cd}$ in the roots and $1.87 \mu \mathrm{g}$, $0.91 \mu \mathrm{g}$ and $0.46 \mu \mathrm{g}$ of $\mathrm{Cd}$ in the leaves, respectively. 
In this study, the reduction of cadmium concentration in the leaves, and roots was related to the enhanced content of $\mathrm{SiO}_{2}$ NPs. Thus this can prove the hypothesis that $\mathrm{SiO}_{2}$ NPs may act as an adsorbent of ions of cadmium, leading to the removal of excess levels of cadmium from the bamboo seedling organs (Table 1).

\section{Microscopy Observation}

\section{Scanning Electron Microscopy Imaging of $\mathrm{Cd}$ and $\mathrm{SiO}_{2}$ NP Absorption by Leaf and Root Surfaces in Moso Bamboo (Phyllostachys edulis)}

Generally, silicon is absorbed as silicic acid from the soil mixture [43]. Silicon can participate in plant organs in different forms, including primarily as amorphous silica (Opal $\mathrm{A} ; \mathrm{SiO}_{2} \cdot \mathrm{nH}_{2} \mathrm{O}$ ) in the cell wall and lumen and as phytoliths in the intercellular space [44,45], where water evaporates from plants [46,47]. Defense mechanisms involving silicon appear throughout plants. It has been shown that the silicon in leaves is used in some leaf structures, such as epidermal hair and trichomes. It has also been reported that silicon can accumulate as amorphous silica and phytoliths in spines [48]. Therefore, in this study, we aimed to demonstrate $\mathrm{SiO}_{2}$ NPs precipitation and accumulation on the leaf and root surfaces of Moso bamboo (Phyllostachys edulis) after seedling growth using SEM. In Figure 6, electron microscopy images show the formation of the $\mathrm{Cd}$ and $\mathrm{SiO}_{2}$ NPs in glands on the leaf surface and the $\mathrm{SiO}_{2} \mathrm{NP}$ accumulation (white spot) in the roots of Moso bamboo (Phyllostachys edulis) seedling.

\section{Discussion}

It is clear that seed germination plays an important role in plant growth and development, as it is the first stage of plant structure formation [49]. On the other hand, it was reported that NPs might help seed germination, seedling vigor and plant photosynthesis [50-52]; it has also been reported that NPs may improve plant vigor under stress conditions [53, 54]. Among them, $\mathrm{SiO}_{2} \mathrm{NPs}$ can ameliorate heavy metal stress in plants [55-57] e.g. in Pisum sativum exposed to $\mathrm{Cr}$ at seedling stage [58]. The main mechanism involved in the amelioration of $\mathrm{Cd}$ toxicity in plants by $\mathrm{SiO}_{2} \mathrm{NPs}$ is related to the stimulation of antioxidant activity so silicon can scavenge ROS compounds by stimulation of antioxidant capacity [59]. Also, $\mathrm{SiO}_{2} \mathrm{NPs}$ with the formation of Si-heavy metals complexes reduces cadmium mobility via some chemical mechanisms [60]. In this study, the results obtained by our data analysis revealed that $\mathrm{SiO}_{2}$ NPs can reduce Cd toxicity in the Moso bamboo (Phyllostachys edulis) at germination stage by increasing the germination index (GI), germination percentage (GP) and germination rate (GR). However, the results showed that $\mathrm{SiO}_{2}$ NPs increased the mean germination time (MGT) in comparison with that in the control. Thus we hypothesized that the adsorption of cadmium ions onto $\mathrm{SiO}_{2}$ NPs could decrease cadmium accumulation in the bamboo seedling leaves. On the other hand, $\mathrm{SiO}_{2}$ NPs led to the restriction of cadmium translocation from the root to the shoot and leaves, which can be cited as a reason for the enhanced germination and seedling growth indexes in our study.

$\mathrm{SiO}_{2}$ NPs can improve plant photosynthesis and plant biomass under stress conditions [61]. Accumulation of excess heavy metals in plants can lead to significant changes in their physiological and biochemical processes, resulting in alterations of vital structures such as plant cell membranes [62, 63] and hampering the translocation and accumulation of nutritional elements within plants $[64,65$,]. The alleviative impact of silicon on heavy metal toxicity in plants might be attributed to the reduction of heavy metal accumulation in plant organs, as observed in the previous studies $[66,67]$. This reduction of metal accumulation can

Table 1. Differential accumulation of cadmium and silicon in the leaves and roots of bamboo seedling.

\begin{tabular}{|c|c|c|c|}
\hline \multicolumn{4}{|c|}{ Leaves } \\
\hline Cadmium treatment concentration & $\mathrm{SiO}_{2}$ nanoparticles concentration & Cadmium accumulation & Silicon accumulation \\
\hline$\mu \mathrm{M}$ & $\mu \mathrm{M}$ & $\mu \mathrm{g}$ & $\mu \mathrm{g}$ \\
\hline 100 & 0 & $1.88 \pm 0.12^{\mathrm{A}}$ & 0 \\
\hline 100 & 100 & $0.91 \pm 0.02^{\mathrm{B}}$ & $1.35 \pm 0.39^{\mathrm{B}}$ \\
\hline 100 & 200 & $0.46 \pm 0.01^{\mathrm{C}}$ & $2.74 \pm 0.80^{\mathrm{A}}$ \\
\hline \multicolumn{4}{|c|}{ Root } \\
\hline Cadmium treatment concentration & $\mathrm{SiO}_{2}$ nanoparticles concentration & Cadmium accumulation & Silicon accumulation \\
\hline$\mu \mathrm{M}$ & $\mu \mathrm{M}$ & $\mu \mathrm{g}$ & $\mu \mathrm{g}$ \\
\hline 100 & 0 & $3.32 \pm 0.21^{\mathrm{A}}$ & 0 \\
\hline 100 & 100 & $1.57 \pm 0.10^{\mathrm{B}}$ & $1.63 \pm 0.04^{\mathrm{B}}$ \\
\hline 100 & 200 & $0.77 \pm 0.06^{\mathrm{C}}$ & $3.32 \pm 0.07^{\mathrm{A}}$ \\
\hline
\end{tabular}


be ascribed to silicon-related mechanisms that block metal transfer and reduce metal uptake in plants [68]. Consequently, silicon reduces metal uptake by limiting or immobilizing metal ions in the growth media and/or influencing influx transporters, which can decrease the transport of metals from the root surface to the shoot xylem [68]. This phenomenon was observed in our study showing that $\mathrm{Cd}$ concentrations were significantly lower in the aerial organs of the bamboo seedling due to the presence of silicon nanoparticles in the growth medium. Nevertheless, the efficiency of this mechanism might depend on various factors, such as plant species, growth
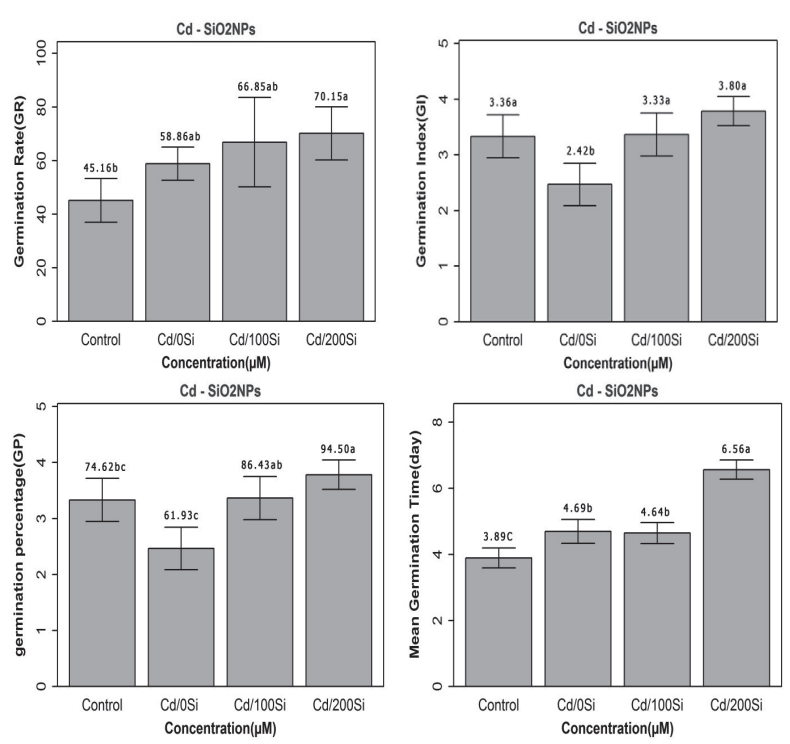

Fig. 2. Effects of the combination of $\mathrm{Cd}$ and $\mathrm{SiO}_{2} \mathrm{NPs}$ on the germination index (GI), germination rate (GR), germination percentage (GP) and mean germination time (MGT) of moso bamboo (Phyllostachys edulis). The treatments included a control treatment and $100 \mu \mathrm{M} \mathrm{Cd}$ alone or in combination with two levels of $\mathrm{SiO}_{2}$ NPs $(100 \mu \mathrm{M}$ and $200 \mu \mathrm{M})$. The letters indicate statistically significant differences among the different treatments according to Tukey's test $(\mathrm{P}<0.05)$.
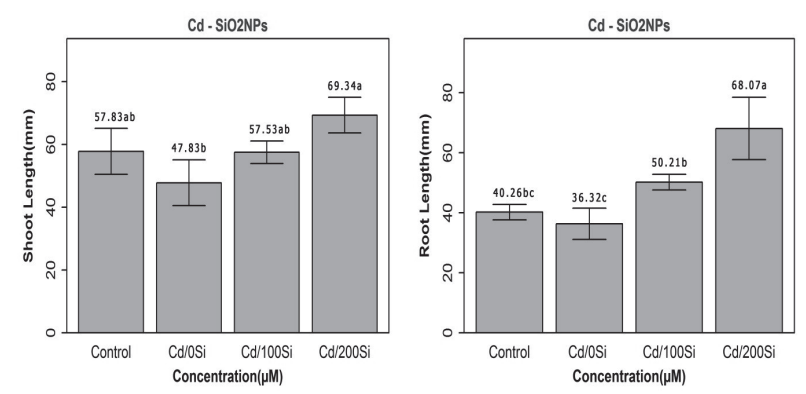

Fig. 3. Effects of the combination of $\mathrm{Cd}$ and $\mathrm{SiO}_{2} \mathrm{NPs}$ on the shoot length and root length of moso bamboo (Phyllostachys edulis). The treatments included a control treatment and $100 \mu \mathrm{M} \mathrm{Cd}$ alone or in combination with two levels of $\mathrm{SiO}_{2} \mathrm{NPs}$ $(100 \mu \mathrm{M}$ and $200 \mu \mathrm{M})$. The letters indicate statistically significant differences across different treatments according to Tukey's test $(\mathrm{P}<0.05)$. conditions, plant genotype, and type and concentration of element, among others [68].

The concentration of silicon increases in the root and shoot with the addition of of $\mathrm{SiO}_{2} \mathrm{NPs}$ in the growth medium and in soil [70]. Silicon accumulation in leaf apoplasts plays an essential role as a barrier for plant protection under stress conditions [71]. Additionally, silicon in the cell membrane can regulate the cell membrane under stress conditions [72]. Moreover, enhanced binding of $\mathrm{Cd}$ to the cell wall leads to the translocation of $\mathrm{Cd}$ to vacuoles and $\mathrm{Cd}$ compartmentalization [73], which is one of the vital mechanisms involved in heavy metal amelioration by silicon. Silicon involved in protein synthesis increased the concentration of protein in fenugreek [74], which can improve plant photosynthesis and plant growth under stress conditions. The results obtained by our study showed that silicon increased the shoot and root length, and reduced the uptake of $\mathrm{Cd}$ by the roots and leaves, which, in turn, can boost the bamboo seedling growth and development under $\mathrm{Cd}$ stress. Silicon improves plant growth and biomass by improving cell
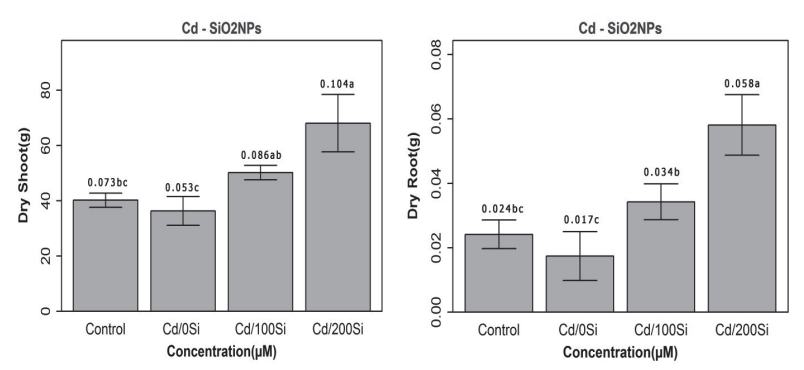

Fig. 4. Effects of the combination of $\mathrm{Cd}$ and $\mathrm{SiO}_{2} \mathrm{NPs}$ on the root and shoot dry weight of moso bamboo (Phyllostachys edulis). The treatments included a control treatment and $100 \mu \mathrm{M}$ $\mathrm{Cd}$ alone or in combination with two levels of $\mathrm{SiO}_{2}$ NPs (100 $\mu \mathrm{M}$ and $200 \mu \mathrm{M})$. The letters indicate statistically significant differences among the different treatments according to Tukey's test $(\mathrm{P}<0.05)$.
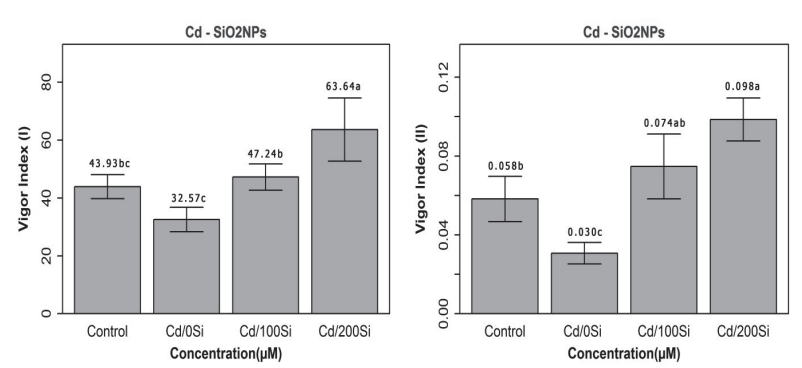

Fig. 5. Effects of the combination of $\mathrm{Cd}$ and $\mathrm{SiO}_{2}$ NPs on vigor index (I) and vigor index (II) in moso bamboo (Phyllostachys pubescens). The treatments included a control treatment and 100 $\mu \mathrm{M} \mathrm{Cd}$ alone or in combination with two levels of $\mathrm{SiO}_{2} \mathrm{NPs}(100$ $\mu \mathrm{M}$ and $200 \mu \mathrm{M})$. The letters indicate statistically significant differences among the different treatments according to Tukey's test $(\mathrm{P}<0.05)$. 


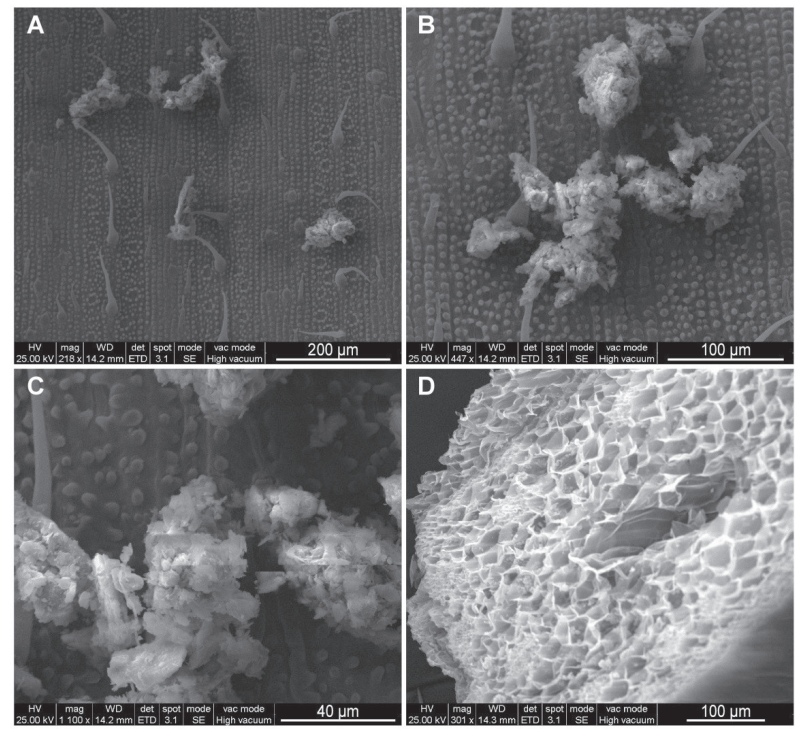

Fig. 6. Leaf and root surfaces from bamboo specimens exposed to the $\mathrm{Cd}$ and $\mathrm{SiO}_{2} \mathrm{NP}$ combined treatment visualized under an environmental scanning electron microscope: (a) bamboo leaf surface with an intact epidermal layer and $\mathrm{Cd}$ and $\mathrm{SiO}_{2}$ NPs in glands; (b) $\mathrm{Cd}$ and $\mathrm{SiO}_{2} \mathrm{NPs}$ in glands on the bamboo leaf surface at high magnification; (c) $\mathrm{Cd}$ and $\mathrm{SiO}_{2} \mathrm{NPs}$ in glands on the bamboo leaf surface at the highest magnification; and (d) the epidermal layer of the root surface covered by $\mathrm{Cd}$ and $\mathrm{SiO}_{2} \mathrm{NPs}$ in Moso bamboo (Phyllostachys edulis) at high magnification.

wall extensibility [69] as well as increasing antioxidant activity in bamboo plants under $\mathrm{Cd}$ stress, which can lead to increased plant photosynthesis and eventually to plant growth and biomass increase. It is reported that $\mathrm{SiO}_{2}$ NPs can raise biomass and yield quality in $\mathrm{Cd}$-stressed rice through reducing $\mathrm{Cd}$ accumulation in roots and increasing antioxidant capacity [75]. Moreover, foliar spray or soil application of $\mathrm{SiO}_{2} \mathrm{NPs}$ are shown to enhance dry biomass of roots, shoots, grains, and spikes in wheat [76]. In this study, the results obtained by our data indicated that $\mathrm{SiO}_{2} \mathrm{NPs}$ application resulted in the increased seedling biomass in Moso bamboo (Phyllostachys edulis) species under $\mathrm{Cd}$ stress. This increase can be attributed to the role of silicon in improving plant nutritional status [75-77]. Alzahrani has reported that silicon reduces cadmium toxicity by increasing the content of $\mathrm{K}+$ in wheat [78], which also showed increased uptake of $\mathrm{S}, \mathrm{K}$, $\mathrm{Mg}$, and $\mathrm{P}$ with silicon treatment under stress conditions [12]. Therefore, we conclude that silicon improves seedling biomass in Moso bamboo (Phyllostachys edulis) under $\mathrm{Cd}$ stress by increasing plant nutrient uptake.

The results obtained from our data indicated that silicon could increase seedling vigor in Moso bamboo (Phyllostachys edulis) under $\mathrm{Cd}$ stress. Ali et al. (2019) reported that increased plant vigor and plant photosynthesis were related to the reduction of $\mathrm{Cd}$ levels in plant tissue by $\mathrm{SiO}_{2} \mathrm{NPs}$, which can improve plant growth under Cd stress. This may have occurred in our study, so we suggest that silicon NPs improves plant vigor in Moso bamboo (Phyllostachys edulis) by reducing its Cd levels [76].

\section{Conclusion}

In our study, the application of $\mathrm{SiO}_{2} \mathrm{NPs}$ significantly ameliorated $\mathrm{Cd}$ toxicity by increasing the seed germination characteristics, i.e., seed germination index (GI), germination percentage (GP), germination rate (GR) and mean germination time (MGT). This enhancement in germination characteristics from the application of $\mathrm{SiO}_{2}$ NPs improved the seedling growth parameters, i.e., shoot and root length and dry weight, as well as seed vigor indexes under Cd stress. We concluded that the accumulation of silicon in the shoots and roots protects bamboo species against $\mathrm{Cd}$ toxicity; so we suggest that the formation of Simetal ion complexations may be responsible for the reduction of cadmium accumulation in the roots and leaves of the bamboo seedling. However, the adsorption of ions of cadmium onto $\mathrm{SiO}_{2}$ NPs could decrease metal accumulation in the roots and leaves. On the other hand, the reduction of silicon translocation from the root to shoot, as well as the stimulation of antioxidant activities by silicon can impact the reduction of cadmium stress in our bamboo seedling study. Additionally, we found that the combination of $100 \mu \mathrm{M}$ Cd with $200 \mu \mathrm{M} \mathrm{SiO}_{2}$ NPs had a greater effect on the reduction of $\mathrm{Cd}$ toxicity in our Moso bamboo than $100 \mu \mathrm{M}$ Cd with $100 \mu \mathrm{M} \mathrm{SiO}_{2}$ NPs (Phyllostachys edulis).

\section{Abbreviations}

Germination index (GI), Germination percentage(GP), Germination rate (GR), Mean germination time (MGT).

\section{Conflict of Interest}

The authors declare that there is no conflict of interests regarding the publication of this paper.

\section{Acknowledgements}

This work was supported by the financial support provided by Nanjing Forestry University (Start-Up Research Fund) and Bamboo Research Institute for the current study. Special Fund for this work was supported by National Key Research \& Development Program of China (Integration and Demonstration of Valued \& Efficiency -increased Technology across the Industry Chain for bamboo, 2016 YFD0600901). 


\section{Author Contributions}

A.E, Y.D and Y.X: statistical analysis A.E and Y.D and Z.A: writing-original draft preparation, A.E., Y.D., and Y.X: Investigation, A.E., Y.D: Supervision, Y.D: Project administration, Y.D.: Funding acquisition, Y.D.,A.E., F.M; revising and English editing of the reviewed manuscript; English editing, by American Journal Express.

\section{References}

1. HU N., LUO Y., WU L., SONG J. Afield lysimeter study of heavy metal movement down the profile of soils with multiple metal pollution during chelate-enhanced phytoremediation. Int. J. Phytoremediation. 9, 257, 2007.

2. ZHAO Q.G., ZHOU B.Z., YANG H. Environmental quality and agricultural safety in Jiangsu Province. Soils. 2002 (1), 1, 2002 [In Chinese with English abstract].

3. ZHANG X., ZHONG T., LIU L., OUYANG X. Impact of Soil Heavy Metal Pollution on Food Safety in China. PLoS One, 10 (8), e0135182. 2015.

4. SHAFIQ M., IQBAL M.Z., MOHAMMAD A. Effect of lead and cadmium on germination and seedling growth of Leucaena leucocephala. J Appl Sci Environ. 12 (2), 61, 2008.

5. CURGUZ V.G., RAICEVIC V., VESELINOVIC M., TABAKOVIC-TOSIC M., VILOTIC D. Influence of heavy metals on seed germination and growth of picea abies L. Karst. Pol J Environ Stud. 12 (2), 355, 2012.

6. CHEN Y.X., HE Y.F., LUO Y.M., YU Y.L., LIN Q., WONG M.H. Physiological mechanism of plant roots exposed to cadmium. Chemosphere. 50, 789, 2003.

7. KHAN M., UNGA I., SHOWALTER A. Effect of Sodium Chloride Treatments on Growth and Ion Accumulation of the Halophyte Haloxylon Recurvum. Commun. Soil. Sci. Plant Annual. 31 (17-18), 2763, 2000.

8. TEERAKUN M., RRUNGSANG A. Determination of Plant Species for the Phytoremediation of Carbofuran Residue in Rice Field Soils. Songklankarine Journal of Science and Technology. 27 (5), 967, 2005.

9. AHMET T., HAYRETTINE K., VEDAT S. Effects of Different Salt Concentration $(\mathrm{NaCl})$ on Germination of Some Spinach Cultivars. Journal of Agricultural of Uludag Unversity, 25 (1), 65, 2011.

10. HADDAD C., ARKOUN M., JAMOIS F., SCHAWARZBENBERG A., YVIN J.C., ETIENNE P., LAÎNÉ P. Silicon promotes growth of Brassica napus L. And delays leaf senescence induced by nitrogen starvation. Fron. Plant Sci. 9, 516, 2018.

11. RIZWAN M., MEUNIER J.D., DAVIDIAN J.C., POKROVSKY O.S., BOVET N., KELLER C. Silicon alleviates Cd stress of wheat seedlings (Triticum turgidum L. cv. Claudio) grown in hydroponics. Environ. Sci. Pollut. Res. 23, 1414, 2016b.

12. CHEN R., ZHANG C., ZHAO Y., HUANG Y., LIU Z. Foliar application with nanosilicon reduced cadmium accumulation in grains by inhibiting cadmium translocation in rice plants. Environ. Sci. Pollut. Res. 25, 2361, 2018

13. PEREIRA T.S., PEREIRA T.S., DE CARVALHO SOUZA C.L.F., LIMA E.J.A., BATISTA B.L., DA SILVA LOBATO A.K. Silicon deposition in roots minimizes the cadmium accumulation and oxidative stress in leaves of cowpea plants. Physiol. Mol. Biol. Plants. 24 (1), 99, 2018.

14. RIZWAN M., MEUNIER J.D., HÉLÈNE M., KELLER C. Effect of silicon on reducing cadmium toxicity in durum wheat (Triticum turgidum L. cv. Claudio W.) grown in a soil with aged contamination. J. Hazard Mater. 209-210, 326, 2012.

15. TAO L., GUO M., REN J. Effects of Cadmium on Seed Germination, Coleoptile Growth, and Root Elongation of Six Pulses. Pol. J. Environ. Stud. 24 (1), 295, 2015.

16. POURKHALOEE A., HAGHIGHI M., SAHARKHIZ M.J., JOUZI H., DOROODMAND M.M. Investigation on the effects of carbon nanotubes (CNTs) on seed germinationand seedling growth of salvia (Salvia microsiphon), pepper (Capsicum annum)and tall fescue (Festuca arundinacea). J Seed Tech. 33 (2), 155, 2011.

17. WHITESIDES G.M. Nanoscience, nanotechnology, and chemistry. Small. 1 (2), 172, 2005.

18. KARIMI J., MOHSENZADEH S. Effects of Silicon Oxide Nanoparticles on Growth and Physiology of Wheat Seedlings. Russ. J. Plant Physiol. 63 (1), 119, 2016.

19. CHENG G., CHANG T., QIN Q., HUANG H., ZHU Y. Mechanical Properties of Silicon Carbide Nanowires: Effect of SizeDependent Defect Density. Nano Let. 14 (2), 754, 2014

20. RAGAB M.A.A., KORANY M.A., IBRAHIM H.Z., ABDEL-KAWI M.A., SAYED A.E.A.A.A. Adsorption behavior of some metal ions on nanoparticles used in pharmaceutical matrices: Application to laboratory made drug formulation. BFPHA, 55, 155, 2017.

21. SIDDIQUI H., AL-WHAIB M.H. Role of nano- $\mathrm{SiO}_{2}$ in germination of tomato (Lycopersicum esculentum seeds Mill.). SAUDI J BIOL SCI. 21 (1), 13, 2014.

22. SURIYAPRABHA R., KARUNAKARAN G., YUVAKKUMAR R., RAJENDRAN V., KANNAN N. Silica nanoparticles for increased silica availability in maize (Zea mays. L) seeds under hydroponic conditions. CURR NANOSCI. 8 (6), 902, 2012.

23. BAO-SHAN L., CHUN-HUI L., LI-JUN F., SHU-CHUN Q., MIN Y. Effect of TMS (nanostructured silicon dioxide) on growth of Changbai larch seedlings. J For Res. 15, 138, 2004.

24. YUVAKKUMAR R., ELANGO V., RAJENDRAN V., KANNAN N.S., PRABU P. Influence of nanosilica powder on the growth of maize crop (Zea mays L.). International Journal of Green Nanotechnology. 3, 180, 2011.

25. HAGHIGHI M., AFIFIPOUR Z., MOZAFARIAN M. The effect of N-Si on tomato seed germination under salinity levels. J Biol Environ Sci. 6, 87, 2012.

26. SIDDIQUI M.H., AL-WHAIBI M.H. Role of nano- $\mathrm{SiO}_{2}$ in germination of tomato (Lycopersicum esculentum seeds Mill.). SAUDI J BIOL SCI. 21, 13, 2013.

27. SLOMBERG D.L., SCHOENFISCH M.H. Silica nanoparticle phytotoxicity to Arabidopsis thaliana. Environ. Sci. Technol. 46 (18), 10247, 2012.

28. LI S., ISLAM E., PENG D., CHEN J., WANG Y., WU J., YE Z.,YAN W., LU K. Accumulation and local-ization of cadmium in moso bamboo (Phyllostachyspubescens) grown hydroponically. Acta Physiol Plant. 37, 56, 2015.

29. GUAN F., XIA M., TANG X., FAN S. Spatial vari-ability of soil nitrogen, phosphorus and potassiumcontents in Moso bamboo forests in Yong'an City,China. Catena. 150, 161, 2017.

30. TANG X., XIA M., GUAN F., FAN S. Spatial Dis-tribution of Soil Nitrogen, Phosphorus and Potas-sium Stocks in 
Moso Bamboo Forests in SubtropicalChina. Forests. 7, 267, 2016.

31. ZHOU M., TAO G., PI P., ZHU Y., BAI Y., MENG X. Genome-wide characterization and evolutionanalysis of miniature inverted-repeat transposableelements (MITEs) in moso bamboo (Phyllostachysheterocycla). Planta. 244, $775,2016 b$.

32. ZHOU M., HU H., LIU Z., TANG D. Two activebamboo mariner-like transposable elements (Ppmarl and Ppmar2) identified as the transposon-based genetic tools for mutagenesis. Molecular Breed-ing. 36, 163, 2016a.

33. HUANG C., HE J., MIN D., LAI C., YONG Q. Understanding the Nonproductive Enzyme Adsorp-tion and Physicochemical Properties of ResidualLignins in Moso Bamboo Pretreated with SulfuricAcid and Kraft Pulping. Applied Biochemistry and Bio-technology, 180, 1508, 2016.

34. WANG H.C., CHOU C.Y., CHIOU C.R., TIAN G., CHIU C.Y. Humic Acid Composition and Charac-teristics of Soil Organic Matter in Relation to the El-evation Gradient of Moso Bamboo Plantations .PLOS One. 1, 11, e0162193, 2016a.

35. BAI S., WANG Y., CONANT R.T., ZHOU G., XU Y., WANG N., FANG F., CHEN J. Can native clonalmoso bamboo encroach on adjacent natural forestwithout human intervention?. Scientific Reports. 6, 38269, 2016.

36. FU W., JIANG P., ZHAO K., ZHAO G., LI Y., WU J., DU $\mathrm{H}$. The carbon storage in moso bamboo plan-tation and its spatial variation in Anji County ofsoutheastern China. Journal of Soils and Sediments. 14, 320-329, 2014.

37. WU W., LIU Q., ZHU Z., SHEN Y. Managing Bamboo for Carbon Sequestration, Bamboo Stemand Bamboo Shoots. Small-scale Forestry. 14, 233, 2015.

38. LI Z-J., LIN P., HE J.Y., YANG Z.W., LIN Y.M. Silicon's organic pool and biological cycle in moso bamboo community of Wuyishan Biosphere Reserve. J Zhejiang Univ Sci B. 7 (11), 849, 2006.

39. COLLIN B., DOELSCH E., KELLER C., PANFILI F., MEUNIER J-D. Effects of silicon and copper on bamboo grown hydroponically. Environ. Sci. Pollut. Res. 20 (9), 6482, 2013.

40. TEKRONY D.M., EGLI D.B. Relaioship of seed vigor to crop yeild .areview . Crop Science. 31, 3816, 1990.

41. KHODARAHMPOUR Z. Evaluation of drought stress effects on germination and early growth of inbred lines of MO17 and B73. Afr. J. Microbiol. Res. 6 (16), 3749, 2012.

42. AGRAWAL R.L., DADLANI M. Seed technology .Second edition. Oxford and IBS publishing .co.PVT.LVT. 1995.

43. EPSTEIN E. Silicon. Ann. Rev. Plant Physiol. Plant Mol. Biol. 50,1999.

44. JONES L.H.P., HANDRECK K.A. Silica in soils, plants, and animals. Adv. Agron. 19, 107, 1967.

45. RAVEN J.A. The transport and function of silicon in plants. Biol. Rev. 58, 179, 1983.

46. SOMMER M., KACZOREK D., KUZYAKOV Y., BREUER J. Silicon pools and fluxes in soils and landscapes: a review. J. Plant Nutr. Soil Sci, 169, 310, 2006.

47. URRIE H.A., PERRY C.C. Silica in plants: biological, biochemical and chemical studies. Ann. Bot. 100, 1383, 2007.

48. HARTLEY S.E., DEGABRIEL J.L. The ecology of herbivore-induced silicon defences in grasses. Functional Ecology. 30, 1311, 2016.

49. ABDUL QADOS A.M.S., MOFTAH A.E. Influence of Silicon and Nano-Silicon on Germination, Growth and
Yield of Faba Bean (Vicia faba L.) Under Salt Stress Conditions. Am. J. Exp. Agric. 5(6), 509-524, 051. 2015.

50. KHAN M.N., MOBIN M., ABBAS Z.K., ALMUTAIRI K.A., SIDDIQUI Z.H. Role of nanomaterials in plants under challenging environments. Plant Physiol. Biochem. 110, 194, 2017.

51. RIZWAN M., ALI S., QAYYUM M.F., OK Y.S., ADREES M., IBRAHIM M., REHMAN M.Z., FARID M., ABBAS F. Effect of metal and metal oxide nanoparticles on growth and physiology of globally important food crops: a critical review. J. Hazard Mater. 322, 2, 2017.

52. SIDDIQUI H., AHMED K.B.M., SAMI F., HAYAT S. Silicon nanoparticles and plants: current knowledge and future perspectives. Springer, Cham, 2020.

53. AIN S., KUMAR A., DHEWA T., PANWAR S., MAJUMDAR R.S. Applications of nanotechnology in agriculture - a review: concepts, aspects, prospects, and constraints. In: Sustainable Biological Systems for Agriculture. Apple Academic Press, 41, 2018.

54. SAXENA A., JAIN A., UPADHYAY P., GAUBA P.G. Applications of nanotechnology in agriculture. J. Nanosci. Nanoeng. Appl. 8, 20, 2018.

55. TRIPATHI D.K., SINGH S., SINGH V.P., PRASAD S.M., DUBEY N.K., CHAUHAN D.K. Silicon nanoparticles more effectively alleviated UV-B stress than silicon in wheat (Triticum aestivum L) seedlings. Plant Physiol. Biochem. 110, 70, 2017.

56. YU Z., HAO R., ZHANG L., ZHU Y. Effects of $\mathrm{TiO}_{2}$, $\mathrm{SiO}_{2}, \mathrm{Ag}$ and $\mathrm{CdTe} / \mathrm{CdS}$ quantum dots nanoparticles on toxicity of cadmium towards Chlamydomonas reinhardtii. Ecotoxicol. Environ. Saf. 156, 75, 2018.

57. RIZWAN M., ALI S., UR REHMAN M.Z., MALIK S., ADREES M., QAYYUM M.F., ALAMRI S.A., ALYEMENI M.N., AHMAD P. Effect of foliar applications of silicon and titanium dioxide nanoparticles on growth, oxidative stress, and cadmium accumulation by rice (Oryza sativa). Acta Physiol. Plant. 41, 32, 2019.

58. TRIPATHI D.K., SINGH V.P., PRASAD S.M., CHAUHAN D.K., DUBEY N.K. Silicon nanoparticles (SiNp) alleviate chromium (VI) phytotoxicity in Pisum sativum (L.) seedlings. Plant Physiol. Biochem. 96, 189, 2015.

59. BIRBEN E., SAHINER U.M., SACKESEN C., ERZURUM S., KALAYCI O. Oxidative Stress and Antioxidant Defense. World Allergy Organ J. 5 (1), 9, 2012.

60. WU, J.-W., SHI, Y., ZHU, Y.-X., WANG, Y.-C., GONG, H.-J. Mechanisms of enhanced heavy metal tolerance in plants by silicon: a review. Pedosphere. 23 (6), 815, 2013.

61. RASTOGI A., TRIPATHI D.K., YADAV S., CHAUHAN D.K., ŽIVČÁK M., GHORBANPOUR M., IBRAHIM EL-SHEERY N., BRESTIC M. Application of silicon nanoparticles in agriculture. 3 Biotech. 9, 90, 2019.

62. NAGAJYOTI P.C., LEE K.D., SREEKANTH T.V.M. Heavy metals, occurrence and toxicity for plants: a review. Environ. Chem. Lett. 8, 199, 2010.

63. AFSHAN S., ALI S., BHARWANA S.A., RIZWAN M., FARID M., ABBAS F., IBRAHIM M., MEHMOOD M.A., ABBASI G.H. Citric acid enhances the phytoextraction of chromium, plant growth 2 and photosynthesis by alleviating the oxidative damages in Brassica napus L. Environ. Sci. Pollut. Res. 22 (15), 11679, 2015.

64. WUANA R.A., OKIEIMEN F.E. Heavy metals in contaminated soils: a review of sources, chemistry, risks and best available strategies for remediation. ISRN Ecol. 2011. 
65. ZIA-UR-REHMAN M., SABIR M., RIZWAN M., SAIFULLAH U., AHMAD H.R., NADEEM M., Remediating cadmium-contaminated soils by growing grain crops using inorganic amendments.K.R. Hakeem, M. Sabir, M. Ozturk, A. Murmet (Eds.), Soil Remediation and Plants: Prospects and Challenges, Elsevier Inc.,/Academic Press, 367, 2015

66. TRIPATHI D.K., SINGH V.P., KUMAR D., CHAUHAN D.K. Rice seedlings under cadmium stress: effect of silicon on growth, cadmium uptake, oxidative stress, antioxidant capacity and root and leaf structures. Chem. Biol. 28, 281, 2012.

67. SHAO J.F., CHE J., YAMAJI N., SHEN R.F., MA J.F. Silicon reduces cadmium accumulation by suppressing expression of transporter genes involved in cadmium uptake and translocation in rice. J Exp Bot. 68 (20), 5641, 2017.

68. ADREES M., ALI SH., RIZWAN M., ZIA-UR-REHMAN M., IBRAHIM M., ABBAS F., FARID M., QAYYUM M.F., IRSHAD M.K. Mechanisms of silicon-mediated alleviation of heavy metal toxicity in plants: A review. ECOTOX ENVIRON SAFE . 119, 186, 2015.

69. HOSSAIN M.T., RYUJI M., SOGA K., WAKABAYASHI K., KAMISAKA S., FUJI S., YAMAMOTO R., HOSON $\mathrm{T}$. Growth promotion and increase in cell wall extensibility by silicon in rice and some Poaceae seedlings. J. Plant. Res. 115, 23, 2002.

70. ASGARI F., MAJD A., JONOUBI P., NAJAFI F. Effects of silicon nanoparticles on molecular, chemical, structural and ultrastructural characteristics of oat (Avena sativa L.). Plant Physiol. Biochem. 127, 152, 2018.

71. SILVA A.J., NASCIMENTO C.W.A., GOUVEIA-NETO A.S. Assessment of cadmium toxicities in potted garlic plants. Acta Physiol. Plant. 38, 211, 2017.
72. MERWAD A.R.M., DESOKY E.S.M., RADY M.M. Response of water deficit-stressed Vigna unguiculata performances to silicon, proline or methionine foliar application. Sci. Hort. 228, 132, 2018.

73. ADREES M., ALI S., RIZWAN M., ZIA-UR-REHMAN M., IBRAHIM M., ABBAS F., QAYYUM M.F., KASHIFIRSHADA M. Mechanisms of silicon-mediated alleviation of heavy metal toxicity in plants: a review. Ecotoxicol. Environ. Saf. 119, 186, 2015.

74. NAZARALIAN S., MAJD A., IRIAN S., NAJAFI .F, GHAHREMANINEJAD F., LANDBERG T., GREGER M. Comparison of silicon nanoparticles and silicate treatments in fenugreek. Plant Physiol. Biochem. 115, 25, 2017.

75. WANG S., WANG F., GAO S. Foliar application with nano-silicon alleviates $\mathrm{Cd}$ toxicity in rice seedlings. Environ. Sci. Pollut. Res. 22, 2837, 2015.

76. ALI S., RIZWANA M., HUSSAINAN A., ZIA UR REHMAN M., ALI B., YOUSAF B., WIJAYAE L., ALYEMENIE M.N., AHMAD P. Silicon nanoparticles enhanced the growth and reduced the cadmium accumulation in grains of wheat (Triticum aestivum L.). PLANT PHYSIOL BIOCH 140, 1, 2019.

77. WANG S., WANG F., GAO S., WANG X. Heavy metal accumulation in different rice cultivars as influenced by foliar application of nano-silicon. Water, Air, Soil Pollut. 227, 228, 2016.

78. ALZAHRANI Y., KUŞVURAN A., ALHARBY H.F., KUŞVURAN S., RADY M.M. The defensive role of silicon in wheat against stress conditions induced by drought, salinity or cadmium. ECOTOX ENVIRON SAFE, 154, 187, 2018. 